\title{
The Islamic Liberation Party Is A Study Of Its Theoretical Foundations And Its Impact On The Political Arena In Iraq
}

\author{
Assist Prof. Mohammed Resen Damman \\ University of Babylon/Faculty of Basic Education/Department of History
}

Article History: Received:11 January 2021; Accepted: 27 February 2021; Published online: 5 April 2021

Abstract: Political parties occupy a large and important place in public life in every society, and in every system of government, while in the democratic system they are an element of this system and one of its institutions, it is impossible to imagine the establishment of the democratic system and the performance of its intended tasks properly without For political parties to fully carry out their duties according to the concepts of this system, it is not the monopoly of democratic systems.

The study of the Islamic parties that emerged after the Second World War in the Arab world is one of the important and dangerous matters because of their clear impact on revealing contemporary thought, especially Islamic thought, as a number of Islamic parties emerged as a result of the ideas of Islamic innovators in the modern era, and as a response to penetration. The emergence of these parties in all aspects of Islamic life came as a response to the phenomenon witnessed by the Islamic community in the modern era.

The research section consists of three topics, in addition to the introduction and conclusion, and a list of the names of the most important sources that have been used in the research.

The first topic covered two axes, the first dealt with political life and the beginning of the emergence of Islamic parties, while the second topic discussed the characteristics of Islamic parties.

As for the second topic, it was divided into three axes, the first axis dealt with introducing the Islamic Liberation Party, while the second axis reviewed the goals and objectives that The Islamic Liberation Party seeks to achieve, and the third axis dealt with the theory of The Islamic Liberation Party in partisan action (the theory of phased action).

The third topic, which consisted of three axes, dealt with the organizational structure of The Islamic Liberation Party and its party organizations, which was the title of the first axis, while the second axis included the constitution of Hizb ut-Tahrir, and the third axis included the activity of the party and its impact on political life.

The first axis:

The beginnings of the formation of Islamic parties

The party is known as a group of people linked by economic interests in the first place, and trying to reach me power through reform or revolution.

In another opinion, the party defined in the communist sense as the (vanguard) of the toiling classes that seek to eliminate exploitation in all its forms and manifestations, and when this party comes to power and establishes the dictatorship of the proletariat, it calls for establishing the dictatorship of the working classes to liquidate exploitation and prepare for the establishment of a classless system.

As for the concept of the party in the Western term, it is a group of people trying, by means of elections, to sit their members in the centers of government, thus controlling or directing government actions.

The party defined the Islamic concept as a group of individuals seeking to apply the principles of the Islamic religion and Islamic law in all aspects of life and return to Islam with its first principles.

As for the political party, it is nothing but one of several types of groups and blocs that under different political systems rule the government apparatus and its policy, which is why the advocates of this concept do not recognize In other party formations that try to reach power in a way other than through elections, they also do not recognize the one-party system (1).

The Islamic parties aimed to change the reality of human society into an Islamic reality by changing concepts, behavior, norms and relations at all levels on the basis of the Islamic faith and ethical bond, and the Islam they adopt is taken from its sources, namely the Holy Qur'an and the Sunnah of the infallible, and through these two concepts the sectarian vision is clear to understand Islam, one of them adopts the guidance of the righteous ancestors, which makes it within the framework, while the other relies on the imams, peace be upon them, in addition to the two main sources, namely the Holy Qur'an and the Sunnah of his Messenger (PBUH). Economics or social relations (2).

And if the difference in the sources of the Islamic understanding is a reason for the difference between some Islamic currents on some issues, then this reason is not dismissed in all sources of difference, as we find the difference with the unity of the sources of understanding, and it may be more painful than the previous one, as the 
matter reached the point of atonement and the description of labor at one party, interest and legal obligation of another party (3).

Accordingly, the emergence of Islamic parties was the result of two things:

1- The expansion of Wahhabi activity and the accompanying prevalence of the takfiri vision of all that it considers polytheism and an attempt to nurture the concept of identification between the trap of the Jahiliyyah and this resort to the use of violence to fight it, as the Messenger (PBUH) used it and resorting to the use of the same descriptions on some Islamic groups.

2- Benefiting from Islamic literature, especially the principle of takfir, while expanding this principle to include the whole society, and a difference in the means of confronting the jahiliyya, while currents spread that believe that the military method is the most capable of confronting the second jahiliyya (4).

The second axis

Characteristics of Islamic parties

The parties were distinguished by a set of characteristics that were unique to them from other political parties, the most prominent of which were:

1- What unites these parties is a commitment to Islam and a call for its arbitration, but the difference in visions seems to be more than a meeting point. Even the Islam that these parties advocate is governed by a sectarian understanding of it, even if the proposals of some of these parties reject sectarianism and call for Islamic unity and overcoming doctrinal differences (5).

2- Most of the Islamic parties have a mass character, as they were not structural parties, but at the same time they were ineffective in dissolving the remnants of the past and the mentality of difference and sectarian and sectarian strife.

3- From the point of origin, it appears that most of these parties are newly formed, even if there are parties with historical extensions that may reach more than a century of time, and that the old parties are characterized by accuracy, organization, depth of political experience and the ability to deal realistically with the event.

4- These parties can be classified in terms of the approach followed in achieving the goals into reform and other coup movements, even if some of them adopt the two approaches together and when necessary, but this does not mean that they deny reform work, rather they want to direct it in a way that serves the change process as (an aspect of the main coup Al-Shamil), and this adoption of one of these two approaches is imposed by the intellectual principles (6).

A movement, as the Islamic thought in its treatment of the Islamic reality is attracted by two currents, one of which says the coup and change by force, and the other believes in advice and guidance and in the most extreme cases adopting the method of civil disobedience. For example, the Islamic Liberation Party, whose founder (Taqi al-Din al-Nabhani) split from the Muslim Brotherhood To deal with the reality, a matter that the political regimes realized its danger to them, and proceeded to restrict his movement and executed most of its leaders (7).

The second axis

Introducing the Islamic Liberation Party, its goals, and its theory of action

The Islamic Liberation Party was established in 1952 in the city of Jerusalem in Palestine, and its founder was the Islamic thinker Taqi al-Din al-Nabhani (8); who explained to the party its principles and objectives in a large number of books (9); and the party described it as a party whose principle is Islam and politics, and it works among the nation and with it to take the principle Restoring Islam to life, the state and society and considers it a fateful issue and thus leads it to the establishment of the caliphate and the restoration of rule according to what God has revealed, and that The Islamic Liberation Party is a political grouping based on the Islamic idea, and it is not a spiritual, priestly, or educational grouping, or a grouping of charitable works, and the Islamic idea on which it is based It is embodied in the group of its members, which calls the nation to it to work with it, and carries it with him to find it in the reality of life, the state and society is the soul of the body of the party, and it is its core and the secret of its life, and it is the link that binds its members (10).

As for the reasons for establishing Hizb ut-Tahrir, its thinkers confirm that the establishment of the party was in response to the Almighty's saying ((Let there be a nation among you who calls for good and enjoins good and forbids evil, and those are the successful ones)), with the aim of resurrecting the Islamic nation from the severe decline it has reached, and liberating it from the ideas of disbelief And its systems and provisions, and from the control and influence of the infidel states in order to restore work to restore the Islamic caliphate state to existence, until the rule returns to what God Almighty has revealed.

The Islamic Liberation Party is based on an idea embodied in a group of its members and works to assimilate the nation with it, and not to be taken by its cause, which are the Islamic idea, that is, the Islamic doctrine and the provisions that emerged from it and the ideas based on it. In society, that is, the embodiment of Islam in governance, 
relations and all other matters of life, and the party has explained everything it adopted in detail in its books and pamphlets that it issued (11).

The party has created a party culture that includes Islamic provisions and calls for Islam as an intellectual leadership from which emerge systems that address human political, cultural, social and economic problems. It is also a political party that includes in its membership women alongside men, and calls all people to Islam and to adopt its concepts and systems, and it depends on Interacting with the nation to reach its goal, and combating colonialism in all its forms and names to achieve the liberation of the nation from its intellectual leadership, uprooting its political, military, economic and cultural roots from the soil of Islamic countries, and changing the misconceptions spread by colonialism from restricting Islam to worship and morals (12).

The thinkers of the Islamic Liberation Party defined the party's work as being summarized in protecting the Islamic call to change the reality of a corrupt society and turn it into an Islamic society, by changing the ideas in it into Islamic ideas so that they become a public opinion among people and concepts that push them to implement and act accordingly, and to change feelings in it until they become Islamic feelings that satisfy When God is pleased, revolted, and angry when God is angry, and changing relations with him until they become Islamic relations that go according to the provisions of Islam and its treatments. It is taking care of people's affairs with the provisions of Islam and its treatments

It appears in these political actions that educating the nation about Islamic culture in order to melt Islam and rid it of corrupt beliefs, wrong ideas and misconceptions, and to be influenced by the ideas and opinions of infidelity, as well as in these political actions the intellectual conflict and political struggle (13).

The intellectual conflict is manifested in the struggle of the ideas and systems of infidelity, as it is manifested in the clash of false ideas and corrupt beliefs by explaining their corruption, showing their error, and declaring the rulings of Islam in them. (14).

The Islamic Liberation Party and its founders justified the goals that their party seeks to achieve and for which the party was founded, and it was a natural response to several negatives that found and took their way to the reality of the Islamic community and its entities, as violent shocks occur in society that make the nation revitalize a natural matter, resulting in a collective feeling It is shared among the members of the nation, leading to an intellectual process to examine the causes and causes of this shock to reach a solution to salvation, and this intellectual process includes the nation's past, present and future, the history of nations and peoples and the means of its revival with comparisons and trade-offs until the mind is guided to the treatment and solution (15).

The party also indicated that the Muslims were exposed at the beginning of the twentieth century to the most violent shake-up that shook their entity, separated their group, and wiped out their state (the Turkish Caliphate State), according to the party's expression, and kept Islam from being applied in life, the state and society.

From this, we see that the fall of the Ottoman Empire is considered one of the most important reasons for establishing Hizb ut-Tahrir, which believes that the Ottoman state was the protector of religion and society, the savior of the Islamic law and the defender of the lives of Muslims.

As for the second reason, it is according to the terminology of the party's thinkers, which includes the conspiracy of the infidel states and their agents from the rulers of the Arab countries that usurped Palestine and established the state of the Zionist entity in it. The Muslims were affected by those two tremors, so The Islamic Liberation Party was established (16).

In addition to these reasons, there were other reasons, including the Muslims 'detachment from ruling by Islamic law, and they began to study Islam in a way that is contrary to the understanding of Islam, because the way to study Islam is to study the rulings of Islam as practical issues for application by the state with regard to it. Moving books, and guiding preachers who repeat the words (sermons) to people without any effect on society.

In addition to this, the hateful West has played a role hateful to Islam and Muslims and its attack on the Islamic religion, as it began to challenge and slander it on the one hand and abhor some of its judgments on the other hand, even though they are the correct treatments for all life problems. Islam would be accused, and they became defenders of it, and this drove them to attempts to interpret the rulings of Islam, for example they viewed jihad as a defensive position or as a defensive and not offensive war, and thus violated the reality of jihad (17).

From this, we conclude that there are several reasons that led to the establishment of the Islamic Liberation Party, according to the opinion of the leaders and thinkers of the party, namely:

1- The fall of the Ottoman Empire (the Islamic Caliphate) as they put it, which led to the disappearance of the defender of the religion and the practitioner of the Sharia of Islam and the domination of Western countries over the Islamic lands.

2- The weakness of Muslims and the Jews' seizure of Arab lands in Palestine with the help of the puppet rulers, and the establishment of the state of Israel on it. 
3 - The spread of ignorance in the Islamic community, which led to the wrong understanding of the principles and concepts of Islam, and even the wrong interpretation of them, prevailed with the weakness of the clerics and mentors.

4 - The penetration of the West in Islamic countries and its description of the treatments of the Islamic religion to the problems of life as untrue even though they are the real and comprehensive solutions to the problems of society, and the Westerners are pushing Muslims to adopt their ideas and their way of life (18).

Party theory in action

(Progressive Work Theory)

The Islamic Liberation Party has defined the initial stages by which it will proceed in order to begin implementing its principles in three stages:

First: the study and learning phase to create a party culture.

Second: The stage of interaction with the society in which he lives until the principle becomes a general custom resulting from awareness and awareness, and the whole group believes in its principle and defends it collectively, and at this stage the principle of struggle between the nation and between those who stand in the way of the principle of colonialism and those who put them before it from the ruling classes and emancipation of foreign culture.

Third: The stage of taking over the reins of power through the nation fully, until the ruling takes a way to implement the principle on the nation, and from this stage the practical phase begins, the practical side of the party begins in the arena of life, and the advocacy side of the principle remains the original work of the state and the party, as the principle is the message that It is borne by the nation and the state (19).

The first stage is considered the founding stage, which is considering all members of the nation as being devoid of every culture, starting to educate those who want to be members of the party with its culture, and considering the whole society as a school for the party, so that the party comes out in the shortest period of time the group that is able to contact the group to interact with it, Provided that this education is not education, and that it is completely different from the school, and therefore the culture of the seminars must be based on the consideration that the principle is the teacher, and that the knowledge and culture that is taken in it is limited to the principle, and to what is required to work with it to go into the battlefield of life, and it starts To carry the call to people after interacting with Islam, because the study he received in the seminars is an influential study to work on in life and carry it to people (20).

As for the second stage, which is the stage of interaction with the nation, which is accompanied by struggle, and this stage is considered very delicate and success in it is evidence of the correct formation of the party, and failure in it is evidence that there is a defect that must be corrected, and it is based on the stage before it.

The third stage is the stage of reaching power, where the party reaches power through the ummah and implements the principle all at once, and that is what is called the coup method, and this method does not accept participation in the government in part, but rather takes the whole ruling and adopts it as a method to implement the principle and not as an end, and it implements the Islamic principle. A coup implementation, and the grading method is not accepted regardless of the circumstances, and when the principle is fully and comprehensively applied, it should carry the Islamic call and make in the state budget a special section for advocacy and propaganda, and it will supervise this call from an international or partisan side according to the circumstances requirements (21).

The third axis

The organizational structure of Hizb ut-Tahrir

And party organizations

- The organizational structure of Hizb ut-Tahrir

And regulatory bodies

The Islamic Liberation Party started its organization from the principle that Islam is universal, so it worked to make its organization centralized comprehensive for all countries, provided that it does not operate from the beginning on a global basis, but must be called to it globally, and to make the field of work for it in every country or countries so that it is stationed in it and then it is established Islamic country (22).

The whole world is a good place for Islamic preaching, except that when the Islamic countries condemn their people to Islam, the da'wah must begin there, and when the Arab countries, which are part of the Islamic countries, speak the Arabic language, which is the language of the Qur'an and hadith, which is an essential part of Islam and an essential element of Islamic culture, so the Arab countries were the first to start carrying this invitation.

And when the party began its emergence and carried it to da'wah in some Arab countries, then it began to naturally expand its campaign of da'wah, until it became operational in many non-Arab Islamic countries.

The Islamic Liberation Party organizational consists of a general leadership headed by the caliph of the party, and the caliph, according to the constitution of the party, is the commander of the army in Islam. Considering that the caliph is the head of state institutions or the supreme governor who presides over the supreme leadership of Hizb ut- 
Tahrir, then the leadership is divided into states, and each state has a leader, and the state in which the party has organizations for the party, so each state is an independent organization of a country, and the leadership of the state one of the people of the country (23). Indeed, the leadership of Iraq could be in the hands of a Lebanese or Jordanian, according to the conditions of the organization and the opinion of the party leadership (24). In Egypt, the Islamic Liberation Party organization or organization was formed under the leadership of Dr. Saleh Sariya, the Iraqiborn Palestinian, and he was a former member of The Islamic Liberation Party in Jordan, and after 1967 it joined the organization in Palestine, and in 1971 it moved to Cairo. Members of worship and good observation closely, worship in private mosques, and that stage represented a first stage in the organization of the benefit of the secret of the members of his organization (25).

The vision of The Islamic Liberation Party was completely different from the Muslim Brotherhood, as there is no unified central organization for the group. Rather, the international organization leaves each country to elect its leadership from among its sons and choose the form of organization and the method of work according to its circumstances, while The Islamic Liberation Party is a closed and highly centralized organization (26).

The Islamic Liberation Party does not require the head of the Islamic government to be poor and considers it a preference condition. It adopts the thesis of (the caliphate), which is the government of the rightly guided caliphs over which the caliph stands and who can demand and disput it. The Khilafah and says: (27) It is not permissible for there to be in this world but one caliph. Their mandate can last for life as long as it exists, God willing (28)

The Constitution of Hizb ut-Tahrir

The Islamic Liberation Party has drawn up an integrated constitution from the point of view of its thinkers. The party shall act according to its provisions in the event that it takes power to bring about the required changes in society and the Islamic state, and the thinkers of The Islamic Liberation Party enact a number of foundations that must be taken and adhered to when writing the constitution and laws to ensure that judges and rulers understand them, and behave. In the legislation the following methods (29):

1- That human problems be studied and that a general constitution be drawn up for them in the form of general general rules or legal provisions, and that they are derived from Islamic jurisprudence (30) provided that they are taken either from the opinion of the mujtahid from the mujtahids with knowledge of their evidence and conviction in them.

2 - That the legal provisions of the law of penalties, rights and others be drawn up on the previous basis in accordance with the constitution with reference to the doctrine and the evidence that the formulation is legally based on general rules to be a jurisprudential reference for judges and rulers.

3- That the legal texts, Islamic jurisprudence and the science of fundamentals of jurisprudence make the reference for interpreting the constitution and the law for judges and rulers so that the means for deep understanding are prepared for them. It has rulings, so the judge rules by the Shari'a ruling that he finds logically in the case, whether this is the opinion of a mujtahid from the mujtahid or an opinion that he has derived with his own diligence (31) 4 - To observe, when deducing judgments and when adopting them, an understanding of reality, jurisprudence in it, and an understanding of the duty in dealing with reality from the legal evidence, which is an understanding of the rule of God in which he ruled in this reality and then applies one of them to the other, in other words to reach knowledge of reality and understanding therein to knowledge of the rule of God. (32).

The Islamic Liberation Party developed the constitution of the Islamic state from an ideological perspective, consisting of (182) articles and (12) chapters, each of which deals with an aspect of the state's life (33).

The Islamic Liberation Party activity in Iraq

Its activity began in the fifties secretly, in 1955 an attempt was made to establish it openly by Messrs. Abdul Aziz Abdul Latif Al-Badri, Hussein Haj Saleh, Abdullah Ahmad Sami al-Dabouni, Abdul-Ghani Muhammad al-Haj Hussein and others, but the Ministry of Interior rejected the request and arrested its founders, and he continued to practice his activities secretly. Until the revolution of July 14, 1958 (34).

The Islamic Liberation Party organizations arrived in Iraq in the mid-fifties at the hands of Jordanian and Palestinian elements, and were able to find a base for it among a number of religious youth who did not match the (Brotherhood) method of Islamic work with their thinking and status. The capital is Baghdad and some southern cities, such as Basra, despite the fact that the party was Sunni in its ideological bases, its sectarian inclination and its leadership (35).

The Islamic Liberation Party did not have a noticeable activity in Iraq during the monarchy, because the party arrived late, and did not have the sufficient base and organizational depth, but in recent years it opposed the policy of Nuri al-Saeed and the Baghdad Pact, which prompted the authority to arrest a group of its members and place them in the prison (Naqrat Salman) (36).

Despite the arrival of the ideas and organizations of The Islamic Liberation Party to Iraq in the mid-fifties, it could not play a role in the political events that Iraq went through. In the period of the last monarchy, we did not 
find for The Islamic Liberation Party any distinguished position among the Iraqi political parties that were known for their positions - at that time. - From various political issues, it did not reach in its activity and organization to the refineries of well-known parties, and one of the small and unknown parties remained among the other parties (37).

As for the period of the end of the fifties and the great event that marked the end of the monarchy and the coming of the republican regime after the revolution of July 14, 1958, we did not find any position of The Islamic Liberation Party in this regard, unlike some Iraqi parties that were known at the time such as the Communist and Nationalist Party and the Baath Party and what they played in moving opinion The general and planning of the revolution, and its existence has proven, while we did not find any role for The Islamic Liberation Party in the events of Republican Iraq before and after the revolution of 14 July 1958 (38)

Despite the passage of many years since its establishment, The Islamic Liberation Party remained in a state similar to closure, given the total ideas it holds and the basic rules of its thinking. The party adopted the internal political and intellectual education method first and foremost as a means to build the elite, then it jumped to the stage of peaceful interaction and collision with non-Islamic entities. Without taking into account the establishment of popular bases or movement on the nation, which makes party members isolated from the angle of counter strikes, as well as their capacity to withstand the fierce challenge of the hostile force.

The Islamic Liberation Party follows the thesis of (seeking victory) in its attempts to gain power, that is to say, relying on the forces that do not fall within the party's organizations, so there is nothing better, for example, than asking for victory from the head of state, the head of another party, a tribal leader, or an ambassador, and the result is that the leaders of The Islamic Liberation Party did not find Those who answer their call when they asked for victory several times and in more than one country, including Iraq.

The Islamic Liberation Party considers itself worthy of sponsoring Muslims and establishing an Islamic caliphate, and it believes that all Islamic movements are contradictory and based on a false basis, and when the party tries to give a general Islamic character to its entity by rejecting sectarianism and sectarianism, it nevertheless surrounded itself with a sectarian and doctrinal trend, which attracts attention in The thinking model of The Islamic Liberation Party is to build all its analyzes and political positions on the basis of the conflict between the English (the old British Empire) and the Americans (the young American empire) as it is called, and it goes that every problem in the world falls within the conflict between these two countries (39).

Conclusion

The Islamic Liberation Party was established in the city of Jerusalem in Palestine in 1952, founded by the thinker and theorist Sheikh Taqi al-Din al-Nabhani. Its work initially focused on Palestine and Jordan and then spread to the rest of the Arab and Islamic countries, including Iraq.

The party was defined as a party whose principle is Islam and politics, and its work, and it works to restore Islam and Islamic law to social life. It is the duty to protect Islam and Muslims, rid the Islamic religion of the incorrect traditions that have been inflicted on it by human beings, respond to the incorrect claims of the West and colonialism against Islam, and adopt the Islamic way of life instead of the Western style and Western culture.

The theory of The Islamic Liberation Party is based on working to reach its goal in power in three phases, the first included education, selection and training of members, and the second included contact with society and convincing it of its ideas to adopt as a method for its life and actions, which leads to mobilizing and winning public opinion and convincing it to turn against reality, and then comes the third phase It is access to power and a coup against reality, whereby the party, through power, makes the necessary changes in social, economic, legal and other life.

The organizational structure of the party was a very closed organizational apparatus, consisting of the general leadership of the party headed by the president of the party and supervising all the party branches in other countries, where the party organizations were divided into states and the general leadership appointed heads of states or branches.

The party's organizations arrived in Iraq in the late 1950s, but it did not play any role in the events that Iraq went through at the end of the monarchy and what followed, just as other parties did, so we did not find any influence on Iraqi politics or the political street.

List of sources

First: Published documents

1. Hizb ut-Tahrir, the State of Iraq, The Islamic Liberation Party Publication Publications, 1953.

2. Hizb ut-Tahrir, Hizb ut-Tahrir's publication on Change, the text of the party's speech in the United States on December 24, 1989. 
3. Hizb ut-Tahrir, The Islamic Liberation Party Concepts Publication, Jerusalem 1954.

4. , the State of the Caliphate, $(\mathrm{dt})$.

5. The Islamic Dawa Party, Munajjuna, Iran 1414.

$6-$ , The Culture of the Islamic Call, C1, Tehran, The Jihad Foundation, (d.

Second: books

6. Ahmad Al-Daour, Provisions of Statements, Dar Al-Ghandour, Beirut, 1965.

7. Ahmed Abdel-Rahim Mustafa, Al-Hilal Socialist Encyclopedia, Cairo, 1968.

8. Taqi al-Din al-Nabhani, The Islamic State, The Arab Press, Jerusalem, 1953.

9. , The Party Bloc, 3rd Edition, Jerusalem, 1953.

11. The Social System in Islam, Dar Al-Ummah, Beirut, 2003.

12. , The Way of Faith, (D.M), 1954.

13.Hassan Shabar, Party Work in Iraq 1908-1958, Arab Heritage House, Beirut, 1989.

14. Hassan Latif Al-Zubaidi, Encyclopedia of Iraqi Parties, Al Ma'arif Foundation, Beirut, 2007.

15. Khalil Mukhaif al-Rubaie, Iraqi Islamic Parties: A Reading in the Endowment and a Vision for the Future, Center for International Studies, University of Baghdad, 2005.

16. Tariq Ismail and Jacqueline Ismail, Government and Politics in Islam, Translated by: Syed Hassan, Center for Arab Civilization, Giza, 1990.

17.Abdul-Jabbar Hassan al-Jubouri, Political Parties and Associations in Iraq 1908-1958, Freedom House for Printing, Baghdad, 1977.

18. Abdul Rahman Al-Maliki, The Penal System, Dar Al-Ghandour, Beirut, 1965.

19. Abd Al-Razzaq Al-Hasani, History of Iraqi Political Parties 1918-1958, Alphabet Center, Beirut, 1980.

20. Laith Al-Zubaidi, The July 14 Revolution in Iraq, Freedom House for Printing, Baghdad, 1979.

21. Majeed Khadduri, Republican Iraq, United House, Beirut, 1974.

22. Nuri Abd al-Hamid al-Ani and Alaa Jassim al-Harbi, History of Iraqi Ministries in the Republican Era, Part 4, Baghdad 2005.

Third: newspapers

1- Al-Zaman Newspaper, No. 6756, February 3, 1960. 